\title{
Patterns of phytoplankton primary productivity in the Neuse River estuary, North Carolina, USA
}

\author{
Joseph N. Boyer ${ }^{1, *}$, Robert R. Christian ${ }^{2}$, Donald W. Stanley ${ }^{1}$ \\ ${ }^{1}$ Institute for Coastal and Marine Resources and Department of Biology, East Carolina University, Greenville, \\ North Carolina 27858, USA \\ ${ }^{2}$ Department of Biology, East Carolina University, Greenville, North Carolina 27858, USA
}

\begin{abstract}
Phytoplankton primary productivity in the Neuse River estuary (North Carolina, USA) was assessed for spatial and temporal patterns over 4 yr as a function of associated influential factors, especially biomass (chlorophyll $a$, chl a) and light. From ${ }^{14} \mathrm{CO}_{2}$-uptake assays maximum photosynthetic rates $\left(P_{\max }\right)$, photosynthesis versus irradiance relationships, daily primary productivity $\left(P_{d}\right)$, and annual primary productivity $\left(P_{y}\right)$ for the system were calculated. Both physical and chemical characteristics of the estuary were profoundly influenced by river flow; this became especially apparent during the near record high flow events of spring 1987. Salinity was depressed throughout the estuary while average photic depth declined. A significant 'washout' of chl a occurred as a result of freshwater input upstream. The effects of this high flow persisted for months after the events and influenced the spatial pattern of primary productivity in the estuary. For the 4 yr period, daily primary productivity ranged from 0.002 to $4.84 \mathrm{~g} \mathrm{C} \mathrm{m}^{-2} \mathrm{~d}^{-1}$ and unlike many estuaries, correlated poorly with $\mathrm{chl}$ a. However, the product of biomass (chl a), photic depth, and surface incident light, $\ln \left(B Z_{\mathrm{p}} I_{0}\right)$, was found to explain $66 \%$ of the variance in $\ln P_{d}$. Pooled data from estuarine stations had a significantly lower slope of the regression line and higher $y$-intercept than riverine stations. This may have been due to the increased biomass specific production $\left(P_{\mathrm{m}}{ }^{\mathrm{B}}\right)$ of the phytoplankton in the mesohaline zone relative to the river species. No significant differences in the relationship of $\ln P_{\mathrm{d}}$ to $\ln \left(B Z_{\mathrm{p}} I_{0}\right)$ were found between seasons or years. There was no better relationship between $P_{\mathrm{d}}$ and any other measured parameters. The 1985 to 1988 annual primary productivity estimates for the Neuse River estuary were 395, 455, 491, and $493 \mathrm{~g}$ $\mathrm{C} \mathrm{m} \mathrm{m}^{-2} \mathrm{yr}^{-1}$ with the mean being $456 \mathrm{~g} \mathrm{C} \mathrm{m}^{-2} \mathrm{yr}^{-1}$
\end{abstract}

\section{INTRODUCTION}

Estimates of daily primary productivity $\left(P_{\mathrm{d}}\right)$ in $\mathrm{g} \mathrm{C}$ $\mathrm{m}^{-2} \mathrm{~d}^{-1}$ and annual primary productivity $\left(P_{\mathrm{y}}\right)$ in $\mathrm{g} \mathrm{C}$ $\mathrm{m}^{-2} \mathrm{yr}^{-1}$ are commonly used to compare estuaries for similarities in trophic state. The calculation of $P_{d}$ for an estuary is a very time and energy intensive proposal which often requires, for every square meter of the system, knowing (1) the relationship between photosynthetic rate and irradiance, (2) the light extinction of the water column, and (3) the solar irradiance for the incubation period. Because of the physical impossibility of sampling large quantities of water, we are left with determining the above parameters for specific

\footnotetext{
- Present address: Institute of Ecosystem Studies, Box AB, Millbrook, New York 12545-0129, USA
}

representative sampling stations and extrapolating these results over the surface area of the estuary. $P_{y}$ is then calculated by extrapolating $P_{\mathrm{d}}$ over time. Therefore, it is crucial to sample the system in a manner that provides adequate coverage over both spatial and temporal scales.

An alternative to direct measurement of $P_{\mathrm{d}}$ for every sampling is mathematical modeling, which uses biological and environmental forcing variables in order to predict $P_{\mathrm{d}}$. Historically, primary productivity has been extrapolated from algal biomass estimations (Riley 1967. Malone 1976). Attempts to predict algal biomass (chlorophyll $a$, chl a) have focused on either light or nutrient availability (Joint \& Pomeroy 1981, Boynton et al. 1982, Wofsy 1983, Harding et al. 1986, Pennock \& Sharp 1986). The consensus is that nutrient limitation supersedes light limitation for control of phytoplankton 
production in oligotrophic systems, but that in moder ately eutrophic estuaries, like that of the Neuse River (North Carolina, USA), light availability should be the most important factor in determining biomass and, subsequently, $P_{\mathrm{d}}$.

Several studies have shown that a strong relationship exists between $P_{\mathrm{d}}$ and some combination of phytoplankton biomass and light availability (Falkowski 1981, Cole \& Cloern 1984, 1987, Harding et al. 1986 , Pennock \& Sharp 1986, Platt 1986, Keller 1988, Platt et al. 1988). Platt (1986) showed that biomass-normalized integral production in the photic zone, $\lambda$, was directly related to available light. Both Cole \& Cloern (1987), in 4 estuarine systems, and Keller (1988), in Narragansett Bay (Rhode Island, USA), showed that a single composite function, the product of phytoplankton biomass, photic depth, and incident light $\left(B Z_{p} I_{0}\right)$, could be used to estimate $P_{d}$. Mallin et al. (1991) found a highly significant relationship existed between $P_{\mathrm{d}}$ and $B Z_{p} I_{0}$ for 3 stations at the mouth of the Neuse River estuary. As Platt et al. (1988) have remarked, the plot of $P_{\mathrm{d}}$ vs $B Z_{p} I_{0}$ is similar to their $\lambda$ vs $I_{0}$. We will call this general modeling approach the 'light $\times$ biomass model'.

Cole \& Cloern (1987) stated that the light $x$ biomass model held only when no other physical or biological factors served to limit phytoplankton production. Therefore, the model would not be applicable for nutrient limited systems. In contrast, Platt (1986) made no mention of the effect of nutrient limitation on $\lambda_{r}$ although it was shown previously that nitrogen limitation occurred frequently if not consistently in the sample area (Platt \& Irwin 1971). In fact, all but one of the data sets used to validate the model by Platt et al. (1988) were from oceanic systems where nutrient limitation is known to occur with regularity. Perhaps the applicability of the light $\times$ biomass model is related to environmental stability; periodic or fluctuating limitation of algal productivity would decrease the fit of light $x$ biomass models, whereas constant limitation by a some factor would not.

Cole \& Cloem (1984, 1987), Keller (1988), and Mallin et al. (1991) relied on data from very few stations within each estuary. The only study that included $>4$ stations throughout the estuarine salinity gradient was the Delaware Bay (USA) (Pennock 1983); however, it was omitted from Cole \& Cloern's (1987) model because of possible nitrogen limitation. Keller (1988) relied on 1 Narragansett Bay station (with varying nutrient additions) to test the model. The study by Mallin et al. (1991) consisted of a 3-station transect across the mouth of the Neuse River estuary. For these reasons, we believe that the applicability of the light $x$ biomass model over the normal salinity range of an estuary has not been adequately addressed.

Some studies have shown that light and biomass estimates are not enough to characterize estuarine productivity over an annual cycle. Pennock \& Sharp (1986) found a poor relationship between productivity and light $x$ biomass through an annual cycle in the Delaware Bay. Keller (1988) also noted this to occur in Narragansett Bay. In both cases, primary productivity was higher in summer and lower in the winter than predicted by light $\times$ biomass models. This effect was attributed to temperature limitation, to changes in species composition from nanoplankton to diatoms, and to zooplankton grazing (Pennock \& Sharp 1986). Therefore, a seasonal component of productivity has not been adequately addressed by the light $x$ biomass model.

There also exists the need to examine the effect of interannual variability on light $\times$ biomass model estimations. Those environmental variables tied to river flow, such as nutrient inputs, water residence time, turbidity, and salinity, fluctuate widely between years in the Neuse River estuary (Christian et al. 1991). Those not tied to flow, such as incident light and temperature. are usually more regular and predictable from one year to the next. If primary productivity is chiefly a function of the underwater light field and biomass, then those factors affecting turbidity and biomass should ultimately determine differences in productivity between years. In the Delaware Bay, Pennock \& Sharp (1986) found no significant relationship between annual primary productivity and their light $x$ biomass model. Conversely, Keller (1988) found that the relationship between $P_{y}$ and annual mean values of $B Z_{p} I_{0}$ was highly significant.

We believe that broad spatial, seasonal, and interannual variability in primary productivity have not been adequately addressed using the light $x$ biomass model. Here we present results from $4 \mathrm{yr}$ of ${ }^{14} \mathrm{CO}_{2}$-productivity measurements in the Neuse River estuary. We chose to address 2 points raised in the above discussion. First, what are the effects of fluctuating environmental variables on the primary productivity of the system? And second, do our data support the empirical light $\times$ biomass approach to modeling phytoplankton productivity especially over large spatial (tens of $\mathrm{km}$ ) and temporal (years) scales?

\section{METHODS}

Study site. The Neuse River begins in the North Carolina piedmont, flows through coastal plain, advances through a well-mixed non-tidal estuary and empties into the Pamlico Sound (Fig 1). It is a large and economically important resource and drains $16000 \mathrm{~km}^{2}$ or about $12 \%$ of the land area of North Carolina (NCDNRCD 1983). The majority of the land 


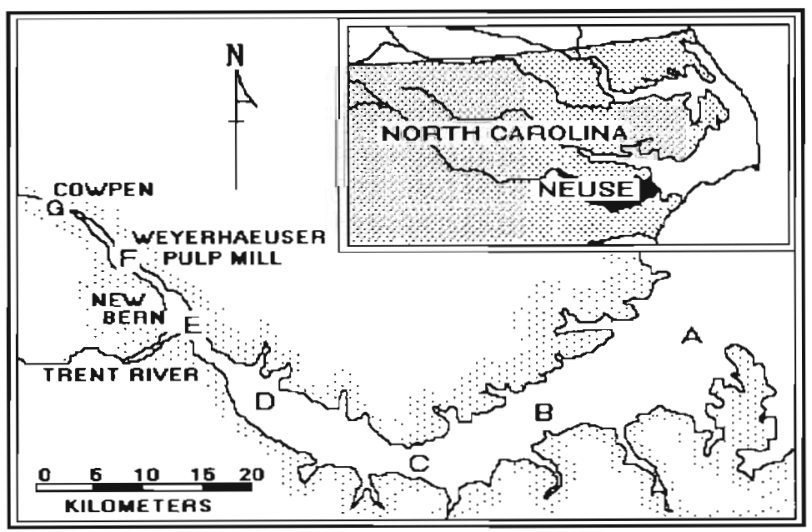

Fig. 1 Stations in the Neuse River estuary (North Carolina, USA) and inset showing Neuse River drainage basin in relation to Albemarle-Pamlico Sound system

mass within the basin is agricultural and forested (ca $88 \%$, and according to a preliminary nutrient budget for the basin (Stanley 1988), $79 \%$ of the total nitrogen loading and $55 \%$ of the total phosphorus loading comes from non-point sources. The remainder comes from 16 municipal and industrial point sources. Most of these are sewage treatment plants, but the largest single discharge is from a paper pulp mill at the head of the estuary above New Bern (between our Stns F \& G).

Median salinities at Stns A, B \& C were not significantly different from each other $(p>0.05)$ but were significantly higher than Stns D \& E which in turn were significantly higher than Stns F \& G (Table 1). Therefore, we defined these zones as the mesohaline estuary, oligohaline estuary, and river, respectively. For statistical purposes, we also defined the estuary as those stations having a median salinity $\geq 3$ ppt and the river as those having a median salinity $<3$ ppt.

Sample collection and analysis. Surface water samples were collected from 7 stations distributed throughout the Neuse River estuary (Fig. 1) at 2 to 3 wk intervals for the 4 yr period beginning March 1985 and ending February 1989; therefore, our operational year

Table 1. Physical characteristics of sampling stations along the Neuse River estuary

\begin{tabular}{|ccccc|}
\hline Stn & $\begin{array}{c}\text { Distance } \\
\text { upriver } \\
(\mathrm{km})\end{array}$ & $\begin{array}{c}\text { Mean } \\
\text { depth } \\
(\mathrm{m})\end{array}$ & Area & $\begin{array}{c}\text { Median } \\
\text { salinity } \\
\left.(\mathrm{km})^{2}\right)\end{array}$ \\
\hline A & 2.41 & 4.32 & 121.7 & 13.1 \\
B & 9.43 & 3.57 & 100.8 & 11.8 \\
C & 24.5 & 2.85 & 88.9 & 9.7 \\
D & 41.4 & 2.53 & 61.4 & 6.3 \\
E & 52.3 & 2.26 & 17.3 & 2.8 \\
F & 63.0 & 2.64 & 3.05 & 0.3 \\
G & 76.3 & 2.20 & 0.56 & 0.0 \\
\hline
\end{tabular}

started in March and ended in February. At each station, dissolved oxygen ( $\left.\mathrm{mg} \mathrm{l}^{-1}\right)$, temperature $\left({ }^{\circ} \mathrm{C}\right)$ and salinity (ppt) were measured at $0.5 \mathrm{~m}$ intervals through the water column using a YSI Model 57 DO meter and a YSI Model $33 \mathrm{~S}-\mathrm{C}$-T meter. Measurements of photosynthetically active radiation (PAR, $\mu \mathrm{E} \mathrm{m}^{-2} \mathrm{~s}^{-1}$ ) were taken every $0.2 \mathrm{~m}$ through the water column using a LI-COR 192SA flat sensor (1985 to 1987) and a 193SB spherical quantum sensor (from 1987) for later calculation of light extinction coefficient $(k)$. Photic depth was defined as the depth of the water column to $1 \%$ of surface irradiance $\left(Z_{\mathrm{p}}=4.61 \mathrm{k}^{-1}\right)$. Total insolation was continuously monitored at East Carolina University using a roof mounted Eppley pyranometer $\left(\mathrm{W} \mathrm{m}^{-2}\right)$. Incident radiation $\left(I_{0}\right)$ as photosynthetically available radiation (PAR; 400 to $700 \mathrm{~nm}$ in $\mathrm{E} \mathrm{m}^{-2} \mathrm{~h}^{-1}$ ) was calculated from this data. The river flow rate was compiled using U.S. Geological Survey gauge data (No. 02089500) which was located $65 \mathrm{~km}$ upstream of our Stn G. Historical river flow data were also obtained from U.S.G.S. records at that gauging station.

Water samples were collected ca $0.2 \mathrm{~m}$ below the surface in gallon polyethylene jugs and kept in the dark at or below ambient temperature. Samples were transported to the laboratory and processed within $7 \mathrm{~h}$ after collection for $\mathrm{pH}, \mathrm{NH}_{4}, \mathrm{NO}_{3}+\mathrm{NO}_{2}$, filterable reactive phosphorus (FRP), dissolved Kjeldahl nitrogen $(\mathrm{DKN})$, particulate nitrogen (PON), particulate phosphorus (PP), and total inorganic carbon (TIC) following U.S. EPA (1979) and APHA (1985) procedures. Chl a was determined by spectrophotometry of acetone extracts with acid correction (Strickland \& Parsons 1972). Chl a values were not available for the first year of the study.

Phytoplankton photosynthesis was measured using the ${ }^{14} \mathrm{C}$-bicarbonate uptake method of SteemannNielsen (1952) as modified by Kuenzler et al. (1979). For 'routine samplings' duplicate samples were incubated at ambient temperatures under either saturating light (393 $\mu \mathrm{E} \mathrm{m}^{-2} \mathrm{~s}^{-1}$ ) or dark conditions. Replicate samples were filtered through $0.45 \mu \mathrm{m}$ cellulose acetate filters (Gelman GN-6) at initiation and twice more for periods up to $6 \mathrm{~h}$. Filters were placed into scintillation vials and air dried overnight. We then added $10 \mathrm{ml}$ of Scintiverse Il cocktail (Fisher) and measured radioactivity using a LKB liquid scintillation counter with external standard correction.

At approximately 3 mo intervals, 'light series' experiments were conducted. Samples from Stns A, D \& G were incubated for ${ }^{14} \mathrm{CO}_{2}$-uptake under a series of neutral density screens representing a range of 6 light intensities ( 0 to $393 \mu \mathrm{E} \mathrm{m}^{-2} \mathrm{~s}^{-1}$ ). These light-series data were used to estimate $\alpha_{f}$, the initial slope of the photosynthesis-irradiance curve (P-I) as normalized to the maximum rate of photosynthesis under saturating light 
conditions ( $P_{\text {inax }}$ ). The $\alpha_{f}$ was used instead of the usual practice of normalizing $\alpha$ to chl a because we did not have chl a values for the first year of the study.

Data analysis. Photosynthetic rates $\left(\mathrm{mg} \mathrm{C} \mathrm{m}^{-3} \mathrm{~h}^{-1}\right)$ at individual light conditions were calculated using the equation of Steeman-Nielsen (1952) as modified by Kuenzler et al. (1979). Each light-series experiment generated both an $\alpha_{\mathrm{f}}$ and $P_{\max }$ at Stns $\mathrm{A}, \mathrm{D} \& \mathrm{G}$ using a modification of the hyperbolic tangent function proposed by Jassby \& Platt (1976). The routine experiments resulted in a $P_{\max }$ for all 7 stations. We assigned the $\alpha_{i}$ values to those other stations in their respective salinity group for that specific date. Additionally, $\alpha_{f}$ was extrapolated between light series experiments for each routine experiment by the $\alpha_{\mathrm{f}}$ for the light series closest in time to the routine sample.

Individual P-I plots of light-series data showed that ${ }^{14} \mathrm{CO}_{2}$ - uptake at $393 \mu \mathrm{E} \mathrm{m}{ }^{-2} \mathrm{~s}^{-1}$ was equivalent to $P_{\max }$ thus we assumed this to be irue for routine experiments. Spatially isolated and infrequent photoinhibition events at the highest light intensity were noted but not deemed significant in the integration calculations as natural mixing would have prevented this occurrence in the field (Randall \& Day 1987, Mallin \& Paerl 1992).

We calculated depth-integrated daily productivity $\left(P_{\alpha}\right)$ by using a discrete depth interval $(0.2 \mathrm{~m})$ integration technique similar to that of Fee (1973) with a modified hyperbolic tangent equation (Jassby \& Platt 1976):

$$
P_{1}=P_{\max } \tanh \left(\alpha_{\mathrm{f}} I_{0} e^{-k z} / P_{\text {max }}\right)
$$

where $P_{\mathrm{i}}=$ hourly production per depth interval $(\mathrm{mg} \mathrm{C}$ $\left.\mathrm{m}^{-2} \mathrm{~h}^{-1}\right) ; P_{\text {max }}=$ maximum photosynthetic rate $(\mathrm{mg} \mathrm{C}$

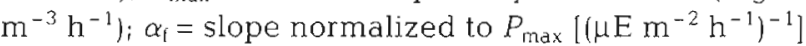
$I_{0}=$ incident $\operatorname{PAR}\left(\mathrm{E} \mathrm{m}^{-2} \mathrm{~h}^{-1}\right) ; k=$ light extinction coefficient $\left(\mathrm{m}^{-1}\right)$; and $z=$ water column depth interval $(m)$. Hourly production values for the $0.2 \mathrm{~m}$ depth intervals, $P_{\mathrm{i}}$, were then summed to give hourly productivity, $P_{\mathrm{h}}$ ( $\mathrm{g} \mathrm{C} \mathrm{m}^{-2} \mathrm{~h}^{-1}$ ) for the whole water column. This procedure was repeated for each hour of the day, and the hourly rates summed to give $P_{\mathrm{d}}\left(\mathrm{g} C \mathrm{~m}^{-2} \mathrm{~d}^{-1}\right)$. This integration approach was repeated for the 7 stations for each of the 82 sampling dates.

Annual primary productivity $\left(P_{y}\right)$ of the system was calculated by first multiplying the $P_{0}$ for each station and date by the surface area of its corresponding segment to arrive at metric tons (t) $C$ segment ${ }^{-1} \mathrm{~d}^{-1}$ These values were then used to calculate kt $C$ segment ${ }^{-1} \mathrm{yr}^{-1}$ by interpolating between sampling dates assuming $P_{d}$ values of measured dates for all dates until halfway to next sampling date. Summing the annual carbon production values for the $7 \mathrm{seg}$ ments gave us total annual carbon production of the whole system which was then divided by the total area of the estuary to give $P_{\mathrm{y}}\left(\mathrm{gC} \mathrm{m}^{-2} \mathrm{yr}^{-1}\right)$.

Data were statistically analyzed for normality and homoscedasticity using probability plots (SYSTAT, Evanston, IL, USA). All pertinent water quality data were normalized using the natural log transformation. Least squares regression analyses were performed on transformed data and coefficients of determination $\left(r^{2}\right)$ were calculated. The median was chosen as the nonparametric statistic of comparison because most of our data were skewed to the right and not easily normalized (see Christian et al. 1991). The 95\% confidence interval of the median as a box-and-whisker plot (McGill et al. 1978; SYSTAT) was used to determine whether differences in variables among stations, seasons, and years were significant $(p<0.05)$. This graphical analysis is a quick and powerful method of comparing grouped data

\section{RESULTS AND DISCUSSION}

\section{Physical and chemical characteristics}

The flow regime of the Neuse River is generally characterized by high flows in the winter/spring followed by low flows in the summer/fall with periodic pulses in summer/fall occurring as a result of rain events (Fig. 2). Compared to the 30 yr mean, this study was conducted during low flow years. However, during the winter/spring of 1986-87, 3 major flooding events occurred in rapid succession. These freshets had long-term effects on nutrient conditions (Christian

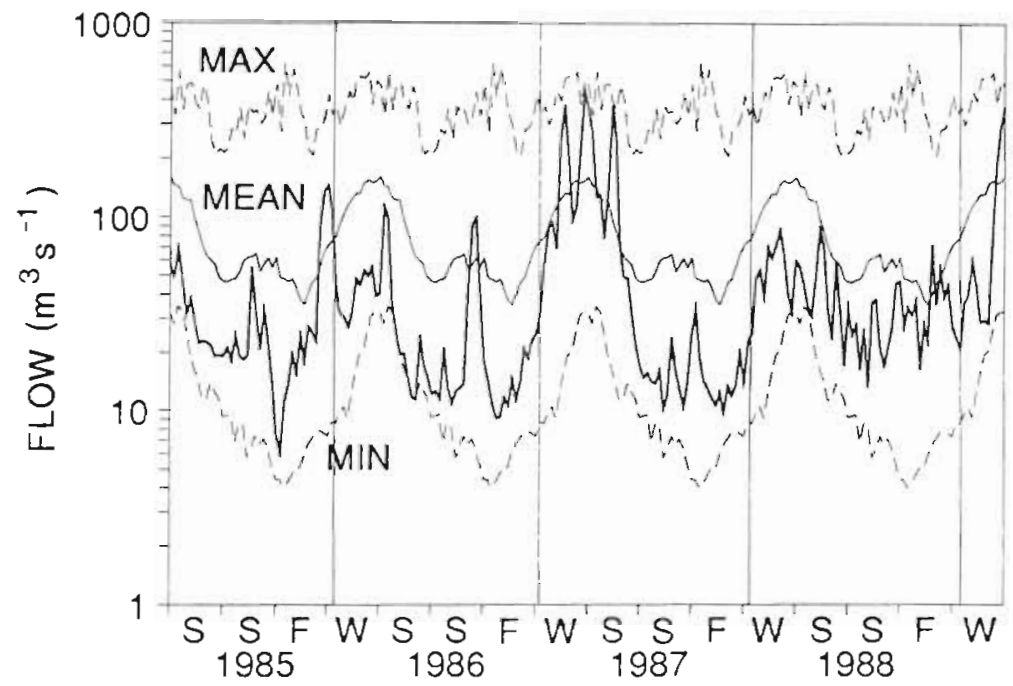

Fig. 2. Neuse River flows at Kinston, North Carolnna (U.S. Geological Survey gauge no. 02089500) 

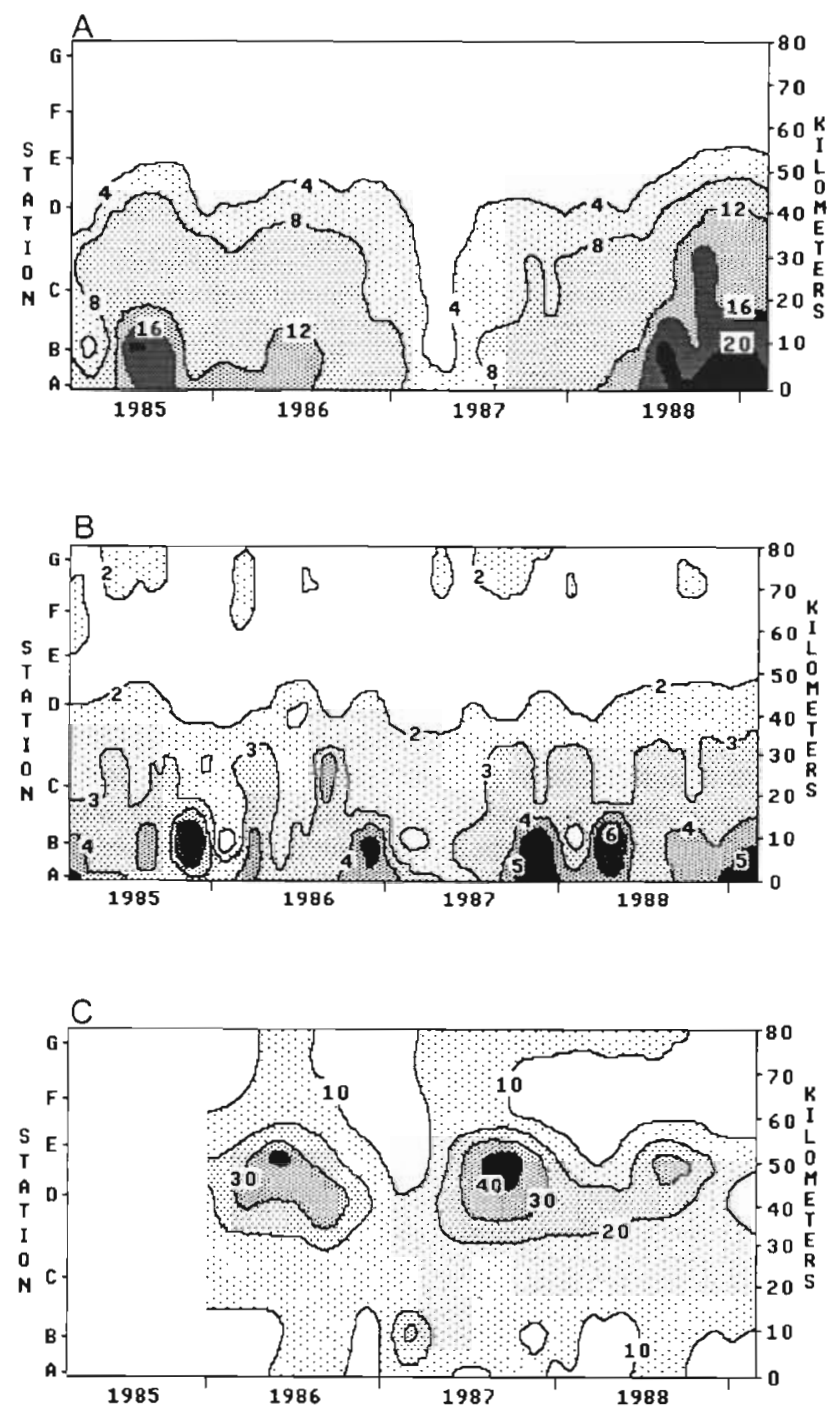

Fig. 3. Isopleths of (A) surface salinity (ppt), (B) $Z_{p}$, photic depth $(\mathrm{m})$, and $(\mathrm{C}) \mathrm{chl}$ a concentrations $\left(\mu \mathrm{g} \mathrm{l}^{-1}\right)$ along the length of Neuse River estuary

et al. 1991), physical conditions, and may have affected biological processes of the system.

Surface salinity of the estuary was significantly lower in the spring than any other season due to normal precipitation patterns (Fig. 3A). In terms of interannual patterns, surface salinity in 1987 was significantly lower than other years as a direct result of the flood events. On one sampling date in May 1987, surface salinity at the mouth dropped to $2 \mathrm{ppt}$, the lowest ever observed during the 4 yr study. This winter/spring flood had a residual effect on salinity that lasted through the summer of 1987 . Perhaps because of the wind patterns during the spring/summer of 1988, a major intrusion of Pamlico Sound water into the estuary occurred with salinities rising to over $26 \mathrm{ppt}$ at the mouth in January 1989.
Photic depth, $Z_{p}$, generally decreased with distance from the mouth of the estuary with the mesohaline zone having significantly greater light penetration than the rest of the system (Fig. 3B). Photic depths ranged from $<1 \mathrm{~m}$ during summer low flow conditions in the river downstream from the paper pulp mill (Stn F) to $>7 \mathrm{~m}$ at the mouth of the estuary. On some sampling dates at or near the mouth, $Z_{p}$ was greater than the average station depth there. Benthic water column exchange of dissolved oxygen was measured during these times and found to contribute to the system's primary productivity (Rizzo et al. 1992).

Measured photic depths in the mesohaline zone during the 1986-87 flood were less than normal for that time of year, having decreased by ca $1 \mathrm{~m}$. Presumably this was due to increased sediment transport by high river flow. Photic depths in the oligohaline zone and river were relatively unaffected by the flood. Apparently, under most conditions the river carries a significant sediment load. The general pattern of highest $Z_{p}$ occurring at the mouth during fall/winter held for all years but for unexplained reasons also showed an early spring peak in 1988. No significant differences in median $Z_{p}$ values within stations were observed among years.

Chl a concentrations in the Neuse River estuary varied by 2 orders of magnitude, ranging from $<1$ to $110 \mathrm{\mu g} \mathrm{l}^{-1}$ In the oligohaline zone, chl a concentrations were significantly higher than those in the mesohaline zone, which were in turn significantly greater than those in the river (Fig. 3C). Highest peak chl a occurred in the oligohaline zone during the spring/ summer of 1986 and summers of $1987-88$. The chl $a$ maximum occurred at the transition zone between the narrow river and broadening estuary (Fig. 1). Depending on river flow, it was also the most probable area where the freshwater-seawater interface occurred. Chl a, i.e. phytoplankton biomass, in the upper estuary was 'washed out' during the winter/spring 1986-87 flood to levels well below normal. Interestingly, winter 1986-87 was the only time we saw evidence of a phytoplankton bloom in the mesohaline portion of the Neuse. This bloom was composed almost entirely of the dinoflagellate Heterocapsa triquetra, a saltwater species. Therefore, the winter bloom was not composed of phytoplankton that were washed out of the river. Another effect of the flood was to rapidly transport $\mathrm{NO}_{3}$ from upriver to the mouth where it is normally present only in very low concentrations (Christian et al. 1991). It is possible that the $H$. triquetra bloom was a direct result of these increased $\mathrm{NO}_{3}$ concentrations. There were no significant differences within means of station chl a concentrations among years. 


\section{Primary productivity}

All of the light series incubations resulted in saturation of ${ }^{14} \mathrm{CO}_{2}$-uptake at or below $393 \mu \mathrm{E} \mathrm{m}^{-2} \mathrm{~s}^{-1}$; therefore, we assumed incubations performed at that light level to be equal to $P_{\max }$. The initial slopes of the lightsenes ${ }^{14} \mathrm{CO}_{2}$-uptake incubations normaluzed to $P_{\max }$

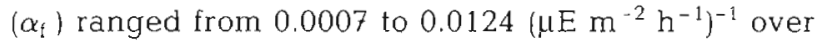
the 4 yr period. Median values of $\alpha_{f}$ by station were 0.0049 (Stn A), 0.0047 (Stn D) and 0.0044 (Stn G). There were no significant differences in $\alpha_{f}$ among stations, seasons, or years.

Maximum photosynthetıc rate ranged from 0.4 to $577 \mathrm{mg} \mathrm{C} \mathrm{m}^{-3} \mathrm{~h}^{-1}$ and was highest in late summerearly fall in the oligohaline zone (Fig 4A). As with chl $a$, there was a noticeable reduction of $P_{\max }$ in the oligohaline zone and increase in the mesohaline zone durng winter/spring 1986-87, presumably due to the residual effect of the phytoplankton wash out upstream and dinoflagellate bloom down estuary. For the 4 yr measured, $P_{\max }$ values were signuficantly higher in the estuary than the nver, but station medians were not different among years.

Assimilation number, $P_{\mathrm{m}}{ }^{\mathrm{B}}$, ranged from 0.14 to $33.9 \mathrm{mg} \mathrm{C} \mathrm{mg}^{-1} \mathrm{chl} \mathrm{a} \mathrm{h}^{-1}$ This range in $P_{\mathrm{m}}{ }^{B}$ was much broader than previously reported for the Neuse River estuary (2.4 to 12.0; Fisher et al. 1982), Delaware Bay
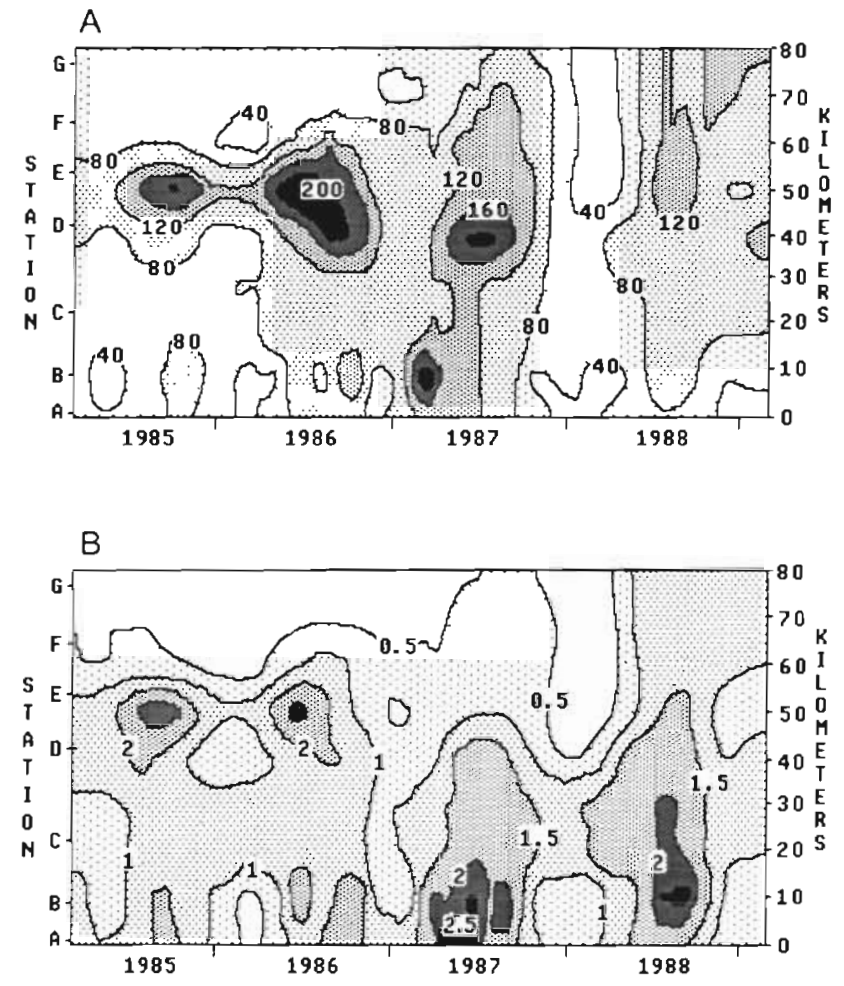

Fig 4 lsopleths of (A) $P_{\max }\left(\operatorname{mg~C~m}{ }^{3} \mathrm{~h}^{-1}\right)$ and (B) $P_{\mathrm{al}}$ $\left(g C \mathrm{~m}^{2} \mathrm{~d}^{1}\right)$ along the length of the Neuse River estuary

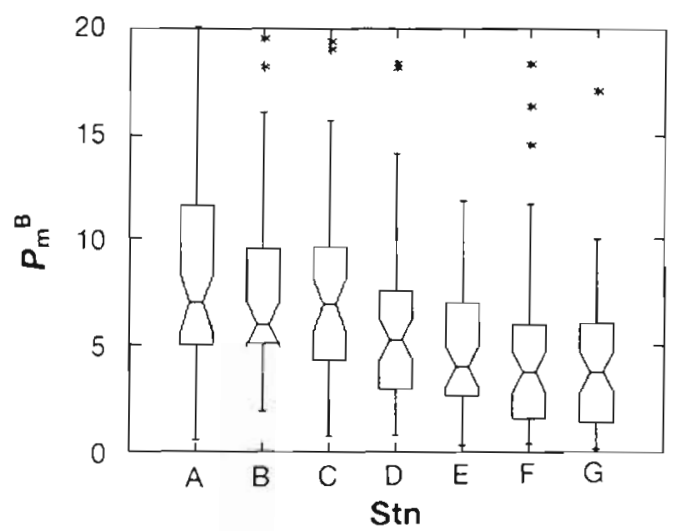

Fig 5. Box plot of $P_{\mathrm{m}}{ }^{B}$ by station in the Neuse River estuary. Medıan is indicated by the horizontal line within each symbol Notches represent the $95 \% \mathrm{Cl}$ around the median. Upper and lower ends of the box are the quartiles, while the ends of the vertical line represent the data range with outliers $(\cdot)$. If the notches of separate boxes do not overlap, their medians are significantly different $(p<0.05)$

(1.0 to 22.7; Pennock \& Sharp 1986), and Chesapeake Bay, USA (1.3 to 10.3; Flemer 1970), but we believe this was a reflection of sampling throughout the salinity gradient. The median of $5.4 \mathrm{mg} \mathrm{C} \mathrm{mg}^{-1} \mathrm{chl} \mathrm{a} \mathrm{h}^{-1}$ was similar to those of the other systems. In general, $P_{\mathrm{m}}{ }^{8}$ declined with distance from the estuary mouth (Fig. 5). Stns A to $C$ had significantly higher $P_{\mathrm{m}}{ }^{B}$ values than Stns $E$ to $G$ This is not unreasonable as the riverine water column is more light limited and, therefore, local phytoplankton communities would be expected to be more shade adapted. No seasonal signal in $P_{\mathrm{m}}{ }^{\mathrm{B}}$ was evident, nor was there any significant relationship to temperature, as had been observed in the Delaware Bay (Pennock \& Sharp 1986). There was a noticeable drop in $P_{\mathrm{m}}{ }^{3}$ durnng winter/spring 1988 , especially in the river and upper estuary, possibly as a result of increased light extinction in the water column from the flood event.

Dally integrated primary productivity varied 3 orders of magnitude from 0.002 to $4.8 \mathrm{~g} \mathrm{C} \mathrm{m}^{-2} \mathrm{~d}^{-1}$. In 1985-86, $P_{\mathrm{m}}$ was highest during summer in the oligohallne zone with smaller peaks near the mouth (Fig. $4 \mathrm{~B})$ After the flood, $P_{\mathrm{d}}$ was highest in the mesohaline zone with very low rates present in the oligohaline portion. It is odd that the major peaks in chl $a$ and $P_{\max }$ during 1985 and 1986 should match up so well with $P_{d}$ but that they would be uncoupled from $P_{\mathrm{d}}$ in 1987-88. It is also interesting to note that after the flood, productivity was relatively high and more uniformly distributed throughout the estuary as a whole $\left(>1.5 \mathrm{~g} \mathrm{C} \mathrm{m}^{-2}\right.$ $\left.\mathrm{d}^{-1}\right\}$, whereas previously, individual peaks in primary productivity occurred at Stn E and the near the mouth (Stn B). This dufferent pattern persisted through 1988 leading us to believe that some fundamental change in the system had occurred as a result of the flood. 
Perhaps the transport and deposition of suspended organic material to the lower estuary fueled benthic remineralization and therefore primary productivity. As noted above, it is also possible that the low flow conditions which induced intrusion of saline Pamlico Sound water had some effect on phytoplankton species composition and productivity.

\section{Empirical modeling}

We observed a significant relationship between lnchl $a$ and $\ln P_{\max }$ in the Neuse River estuary $(\mathrm{p}<0.001)$, however chl a explained only $55 \%$ of the variance in $P_{\max }$. Much better regressions between $P_{\max }$ and chl a have been shown to exist for other estuaries (Malone 1976, Boynton et al. 1982, Cole \& Cloern 1984, 1987, Pennock \& Sharp 1986, Mallin et al. 1991). In the Neuse, we found that the relationship between $\ln P_{\max }$ and ln chl a varied with salinity. Stations with salinity $\geq 3$ ppt exhibited a lower slope and higher $y$-intercept $\left(y=0.63 x+2.66, \mathrm{r}^{2}=0.441, \mathrm{n}=182\right)$ than those with salinity $<3$ ppt $\left(y=1.10 x+1.15, \mathrm{r}^{2}=0.557, \mathrm{n}=129\right)$.

The regression equation of natural logged data, $\ln \left(P_{\max }\right)=a \ln ($ chl $a)+b$ can be back transformed to a power curve, $P_{\max }=(\mathrm{chl} a)^{a} \times b$. In this case, $a$ is really a parameter of the power curve that determines its deflection from linearity while $b$ determines the initial aspect ratio of the curve. From the power equation it can be shown that if $0<a<1$, the line curves downward and as $a \rightarrow 1$, the curve becomes linear. The power equation also demonstrates that as $b$ increases, the initial aspect ratio increases and that as $b->0$, the the data fit a 1:1 correspondence.

The advantages of using natural log transformed

Table 2. Linear regression analyses of $\ln P_{\mathrm{d}} v s \ln \left(B Z_{\mathrm{p}} I_{0}\right)$ for all data, data pooled by station, and by salinity (ppt). Also included is the contribution of In (chl a) to the variance of the light $x$ biomass model. SE of the slope is given in parentheses. Statistical significances of the $y$-intercept being different from the origin are given as: NS, $p>0.05 ;{ }^{*} p<0.5 ; \cdots p<0.01 i^{*} \cdots p<0.001$

\begin{tabular}{|c|c|c|c|c|c|c|}
\hline \multirow[t]{2}{*}{ Stn } & \multicolumn{5}{|c|}{$\ln \left(B Z_{\mathrm{p}} I_{0}\right)$} & \multirow{2}{*}{$\begin{array}{c}\ln (\mathrm{chl} a) \\
\mathrm{r}^{2}\end{array}$} \\
\hline & $a(\mathrm{SE})$ & & 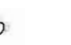 & $r^{2}$ & $\mathrm{n}$ & \\
\hline All & $0.96(0.04)$ & -0.08 & NS & 0.663 & 335 & 0.432 \\
\hline A & $0.71 \quad(0.09)$ & 2.00 & $\cdots$ & 0.523 & 57 & 0.284 \\
\hline B & $0.53(0.10)$ & 3.25 & $\cdots$ & 0.431 & 41 & 0.319 \\
\hline C & $0.71 \quad(0.13)$ & 1.99 & $\cdot$ & 0.436 & 41 & 0.110 \\
\hline D & $0.64 \quad(0.09)$ & 2.28 & $\cdots$ & 0.464 & 55 & 0.173 \\
\hline E & $0.94 \quad(0.10)$ & -0.08 & NS & 0.684 & 46 & 0.596 \\
\hline$F$ & $0.94 \quad(0.14)$ & -0.27 & NS & 0.512 & 42 & 0.357 \\
\hline $\mathrm{G}$ & $0.95(0.12)$ & -0.45 & NS & 0.569 & 53 & 0.529 \\
\hline $\mathrm{Sal} \geq 3$ & $0.65(0.05)$ & 2.31 & $\cdots$ & 0.465 & 182 & 0.168 \\
\hline $\mathrm{Sal}<3$ & $1.02(0.07)$ & -0.68 & NS & 0.644 & 129 & 0.555 \\
\hline
\end{tabular}

data become obvious when attempting to interpret the logged regression equation. First, the data are transformed to fit the binomial distribution and are available for parametric statistical analyses. Second, the slope of the logged regression line, $a$, describes the curvilinear relationship of the raw data. In this case, data from stations with salinity $<3$ are linearly related while those with salinity $\geq 3$ are nonlinear. Third, the $y$-intercept of the logged regression line, $b$, describes the photosynthetic efficiency of the phytoplankton. Phytoplankton from higher salinity waters fix more $\mathrm{CO}_{2}$ per unit chl a than do those upstream. This was previously discussed, when $P_{\mathrm{m}}{ }^{\mathrm{B}}$ was also shown to decline with decreasing salinity.

We have already shown that chl a is a reasonably good predictor of photosynthetic activity but that there were differences in the relationship between $P_{\max }$ and chl a between the estuary and river. Taking this one step further, we wanted to see if variations in integrated primary productivity were also predictable. We found that in chl a explained $43 \%$ of the variance in $\ln P_{\mathrm{d}}$ (Table 2 ) and that neither $\ln Z_{\mathrm{p}}$ nor $\ln I_{0}$ alone was useful in predicting $\ln P_{\mathrm{d}}$ (data not shown). A more robust regression $\left(r^{2}=0.663 p<0.0005\right)$ was obtained between $\ln P_{\mathrm{d}}$ and the light $\times$ biomass model, $\ln \left(B Z_{\mathrm{p}} I_{0}\right)$. The slope of the regression line for all data was 0.96 and the $y$-intercept was not significantly different from zero (Table 2).

All previous analyses of light $x$ biomass models were performed using untransformed data (Cole \& Cloern 1984, 1987, Pennock \& Sharp 1986, Keller 1988 , Mallin et al. 1991). The light $x$ biomass model did not fit our untransformed data $\left(\mathrm{r}^{2}=0.50\right)$ nearly as well as it did for San Francisco Bay, USA $\left(\mathrm{r}^{2}=0.82\right.$; Cole \& Cloern 1987), Narragansett Bay $\left(r^{2}=0.82\right.$; Keller 1988), and the Neuse River transect $\left(\mathrm{r}^{2}=0.73\right.$; Mallin et al. 1991). However, data from Delaware Bay, the only other study with stations distributed across a salinity gradient, did not fit the model as well either $\left(r^{2}=0.68 ;\right.$ Pennock \& Sharp 1986). Aside from comparing non-normally distributed parameters, this approach also assumed that the relationship between $P_{\mathrm{d}}$ and $B Z_{\mathrm{p}} I_{0}$ was linear, mostly because there was no reason to suspect otherwise.

In the above studies, differences in slopes of light $x$ biomass regressions between seasons, stations, experimental treatments, and even individual estuaries were identified. Pennock \& Sharp (1986) postulated that 'increased slope appears to be caused by the shift in species composition from diatoms to 
nanoplankton (with higher $P_{\mathrm{m}}{ }^{\mathrm{B}}$ ) in the lower estuary" Keller (1988) attributed low slopes in the highest nutrient addition mesocosms to 'alterations in species composition and size distribution, away from the expected summer dominance by small phytoplankton with high productivity'. None of the previously mentioned studies attempted to analyze the significance of the $y$-intercept in the regression equation. We now believe that a model with a $y$-intercept significantly different from zero is an artifact of performing parametric regression analysis using non-normally distributed data.
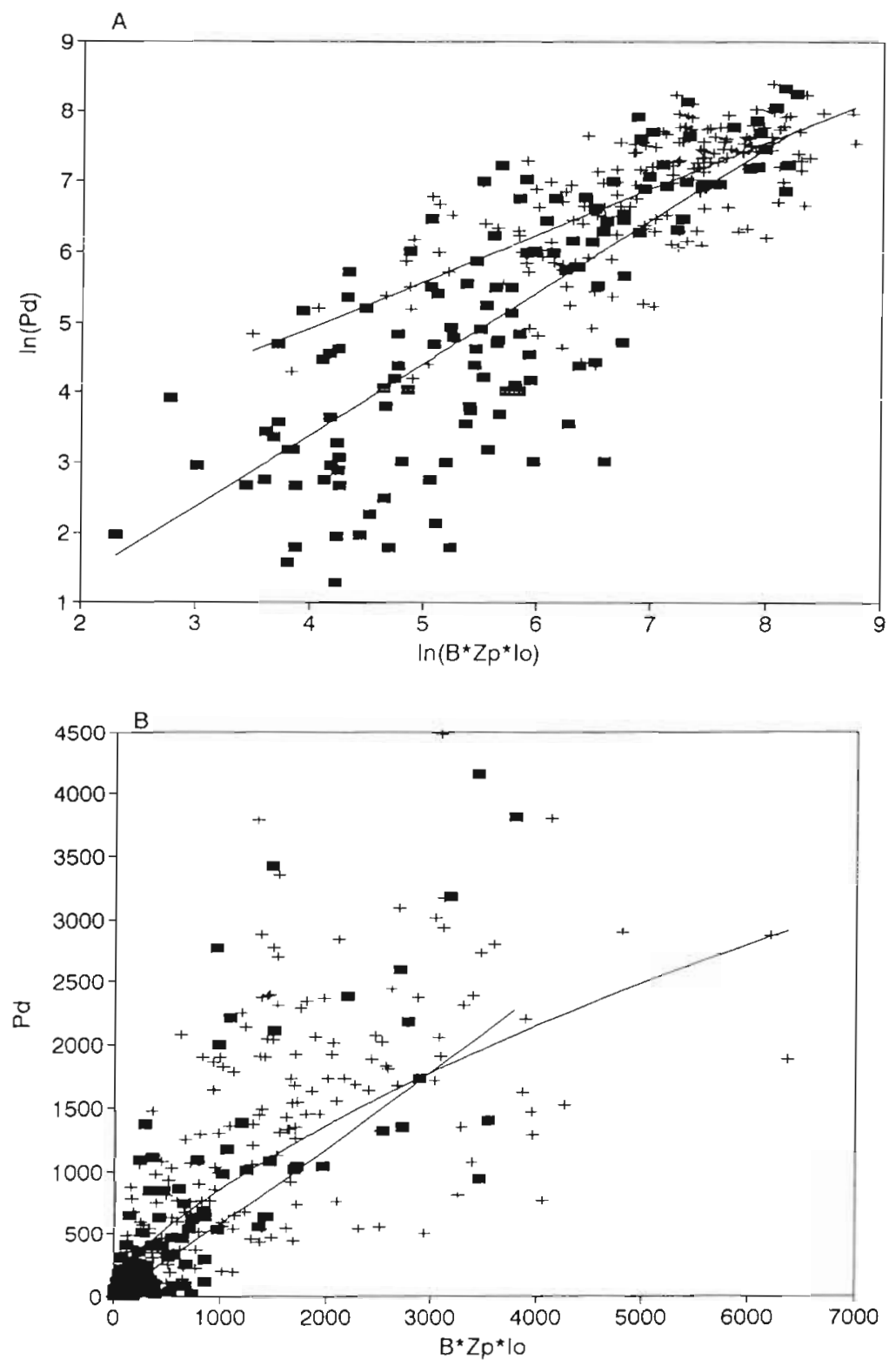

- Sal<3ppt $+\mathrm{Sal}>=3 \mathrm{ppt}$

Fig. 6. (A) Linear regression using $\ln P_{\mathrm{d}}$ vs $\ln \left(B Z_{\mathrm{p}} I_{0}\right)$. Data are grouped into salinity $\geq 3$ ppt $\left(\mathrm{r}^{2}=0.473\right)$ and salinity $<3$ ppt $\left(\mathrm{r}^{2}=0.647\right)$. (B) Raw data from (A) fit using power curve derived from regression analysis
Natural log transformation of the data with subsequent regression analysis has provided new insight by describing the original relationship between $P_{\mathrm{d}}$ and $B Z_{p} I_{0}$ as a power curve. We analyzed data from individual stations in order to determine if there were spatial differences in model fit. Regression analysis of natural logged data showed differences in slopes and $y$-intercepts among stations (Table 2). The estuarine Stns $A$ to $D$ had lower slopes and higher $y$-intercepts than the lower salinity Stns E to G (Fig. 6A). The break occurred around a salinity level of 3 ppt. For stations $\geq 3 \mathrm{ppt}$, the slope of the regression line was 0.65 with a $y$-intercept of 2.31 . For stations $<3$ ppt salinity, the slope was 1.02 and the $y$-intercept was not significantly different from zero. It is important to understand that these slopes and $y$-intercepts are from natural log transformed data. The raw data are shown in Fig. 6B with power curves back-calculated from the linear regression equations. It is clear that the power curve must pass through the origin whether it is linear or not. The slope of the logged regression line, $a$, describes the presence and amount of limitation to primary productivity not predicted by biomass, photic depth, or irradiance. The $y$-intercept, $b$, describes the photosynthetic efficiency of the phytoplankton making up the system before any limitation occurs. The low a value (0.65) for stations with salinity $\geq 3 \mathrm{ppt}$ means that primary productivity became limited by some factor or factors other than biomass, photic depth, and irradiance when it should have been highest. Another reason for this may be due to the shallow depth of the system. As previously mentioned, there were times when the photic depth exceeded the actual water column depth. The light $x$ biomass model assumes that all of the photic depth is used in $\mathrm{CO}_{2}$ fixation. When photic depth exceeded water column depth the light $\times$ biomass model overestimated $P_{d}$.

It is possible that the high $b$ value of the estuary was due to greater photosynthetic efficiency of phytoplankton in the estuary as evidenced by their higher mean $P_{\mathrm{m}}{ }^{\mathrm{B}}$. However, the higher efficiency is only necessary under low $B Z_{p} I_{0}$ conditions. The curve for the estuary (salinity $\geq 3 \mathrm{ppt}$ ) is characterized by higher aspect ratio at low light field conditions, when $B Z_{p} I_{0}$ is limiting (Fig. 6B). As $B Z_{p} I_{0}$ increases, 
productivity becomes limited by some other factor. In contrast, the riverine portion possesses a lower photosynthetic efficiency but is not limited under high $B Z_{p} I_{0}$ conditions.

The main distinction in model fit between estuary and river is due to dependence on chl a. For the estuarine zone having a salinity $\geq 3 \mathrm{ppt}$, In chl a accounted for only $17 \%$ of the variance explained by the light $x$ biomass model (Table 2). The underwater light field was the most important factor in determining $P_{\mathrm{d}}$ in the estuarine zone. Under typically low light extinction, any small increase in irradiance resulted in a large increase in $Z_{p}$ and therefore $P_{0}$. Under high irradiance and low light extinction with normal mixing conditions (Mallin \& Paerl 1992), the algae were not in the dark for any appreciable time. Therefore, it is possible that some photoinhibition could have occurred at these times. In contrast, for those stations having a salinity $<3 \mathrm{ppt}, 56 \%$ of the explained variance in $\ln P_{\mathrm{d}}$ was due to ln chl a (Table 2). It is clear that chl a concentration in the low salinity, riverine portion is most important in determining $P_{\mathrm{d}}$. In this zone of high light extinction, large changes in irradiance would have little effect on photic depth and, therefore, $P_{d}$.

In pooled data we did not observe the seasonal shifts in slope of the regression line as was seen in other studies (Pennock \& Sharp 1986, Keller 1988). We believe this was due in part to the fact that no seasonal trends were apparent in either $\alpha_{\mathrm{i}}$ or $P_{\mathrm{m}}{ }^{\mathrm{B}}$. This was also the case when data were separated into the above salinity groups. No differences in $a$ or $b$ of the model were found between years. This was encouraging because it demonstrated the robustness of the relationship between primary productivity and light $x$ biomass estimates over very different river flow regimes (Fig. 2).

Contrary to the results of a study performed in the Neuse by Mallin et al. (1991), no significant correlation was found between either $P_{\max }$ or $P_{\mathrm{d}}$ and $\mathrm{NO}_{3}$ concentration for any of the mesohaline Stns A to $C$. No significant correlation was evident, even when only 1988 data was used (the year in common). It seems likely that by holding water samples for $24 \mathrm{~h}$ before performing the assay and conducting longer incubations they may have inadvertently promoted nutrient limitation in the incubation vessel and lowered their estimates of phytoplankton productivity. It is also possible that sufficiently strong nutrient limitation occurred in 1989 to promote a significant correlation for the whole data set. However, we must emphasize that observing a significant relationship between primary productivity and nitrate concentration in one area of the estuary for one of the 5 combined years of study does not mean that the Neuse River estuary is a $\mathrm{NO}_{3}$ limited system.

\section{Annual primary productivity}

On an areal basis (see Fig. 1), for all years, more than $99 \%$ of the total primary production $\left(\mathrm{kt} \mathrm{C} \mathrm{yr}^{-1}\right)$ of the Neuse River estuary occurred in the estuarine portion (Stns A to E) of the system; of this $75 \%$ fell within the mesohaline zone (Table 3). This distribution was due primarily to geomorphological and physical conditions of the estuary below New Bern. Although high peaks in $P_{\max }$ and $P_{\mathrm{d}}$ occurred in the river and oligohaline zone, the large surface area and deep photic depth of the mesohaline zone completely overwhelmed the contribution of the upper portions.

Average annual integrated productivity for the Neuse River estuary was $395,455,491$, and $493 \mathrm{~g} \mathrm{C} \mathrm{m}^{-2}$ $\mathrm{yr}^{-1}$ with the mean for the $4 \mathrm{yr}$ being $456 \mathrm{~g} \mathrm{C} \mathrm{m}^{-2} \mathrm{yr}^{-1}$. Annual primary productivity in the Neuse was high when compared to other river-dominated estuaries (Boynton et al. 1982, Nixon \& Pilson 1983, Pennock \& Sharp 1986, Mallin et al. 1991) but was quite comparable to the $500 \mathrm{~g} \mathrm{C} \mathrm{m}^{-2} \mathrm{yr}^{-1}$ reported by Kuenzler et al. (1979) for the neighboring Pamlico River estuary.

Mallin et al. (1991) attempted to define the annual primary productivity of the lower Neuse River estuary by taking monthly samples along a 3 station transect at the mouth (our Stns A \& B) over a period of 2 yr. Their average annual productivity for 1988 was ca $200 \mathrm{~g} \mathrm{C}$ $\mathrm{m}^{-2} \mathrm{yr}^{-1}$ (our estimate). In this study, $P_{y}$ for 1988 at Stn A was $373.7 \mathrm{~g} \mathrm{C} \mathrm{m}^{-2} \mathrm{yr}^{-1}$. It is possible that the discrepancy between these measurements was due to differences in methodology. Their incubations were conducted a full day after collection under natural light while ours were performed within $5 \mathrm{~h}$ after collection but under artificial illumination. In addition, their incubation periods were longer and their depth integration model was different from ours. However, it is more important to note that the difference between $P_{y}$ estimates becomes even greater when all the other stations along the salinity gradient are included in the calculations. Our total 1988 productivity for the Neuse

Table 3. Total mass of carbon fixed per year for each segment

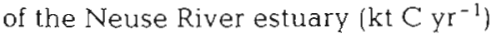

\begin{tabular}{|lcccc|}
\cline { 2 - 5 } Stn & 1985 & 1986 & 1987 & 1988 \\
\hline A & 44.7 & 52.8 & 62.3 & 45.5 \\
B & 36.0 & 44.0 & 48.8 & 53.4 \\
C & 32.1 & 34.9 & 41.7 & 42.8 \\
D & 30.4 & 33.5 & 33.7 & 42.9 \\
E & 11.0 & 12.1 & 5.11 & 7.87 \\
F & 0.45 & 0.60 & 0.54 & 0.15 \\
G & 0.10 & 0.12 & 0.13 & 0.02 \\
Total & 154.7 & 178.2 & 192.3 & 192.6 \\
\hline
\end{tabular}


River estuary was $493 \mathrm{~g} \mathrm{C} \mathrm{m}^{-2} \mathrm{yr}^{-1}$ or almost 2.5 times that determined by Mallin et al. (1991).

In searching for simple models, major simplifications in conceptual design must be made. In the Neuse River estuary, much, but not all spatial and temporal variation in $p_{d}$ was accounted for using this approach. What remains to be found are the factors that drive the forcing variables Chl $a$ and $Z_{p}$. River flow seems to be important in determining $Z_{p}$, but what determines phytoplankton biomass and specific activity remains to be shown. Obviously, there is more to modeling estuarine productivity than describing statistical relationships among variables. We estimated these parameters through regression but there is no provision in this type of model to predict them by mechanistic equations. Therefore, we cannot use the light $x$ biomass model to generate primary productivity if conditions change which alter statistical relationships (e.g. species composition). It has value in interpretation of previously collected data and allows us to expand the sampling design without increasing the workload (Cole \& Cloern 1987). More importantly, before acceptıng or rejecting an empirical model, its use must be strictly defined. The light $x$ biomass model was useful for determining primary productivity on a broad scale, both in area and time. For working in a finer scale, such as diel patterns, it would be more appropriate to use a general deterministic model.

Acknowledgements. The authors thank A. Anderson, W. Bryant, D. Daniels, T. Gurganis, L. Harper, M. Jones, G. Lackey, A. Larkins and R. Willis for laboratory and field assistance. We also thank $W$. Rizzo and 2 anonymous reviewers for constructive comments on the manuscript. Support for this work was provided by the National Oceanic and Atmospheric Administration Office of Sea Grant under grant no. NA85AA-D-SG022, and the State of North Carolina and by the U.S. Environmental Protection Agency under grant agreement R-812475-01-0.

\section{LITERATURE CITED}

APHA (American Public Health Association) (1985). Standard methods for the examination of water and wastewater, 16th edn. American Public Health Association, New York

Boynton, W. R., Kemp, W. M., Keefe, C. W. (1982). A comparative analysis of nutrients and other factors influencing estuarine phytoplankton production. In: Kennedy, V S (ed.) Estuarine comparisons. Academic Press, London, p. $69-90$

Christian, R. R., Boyer, J. N., Stanley, D. W (1991). Multi-year distribution patterns of nutrients within the Neuse River Estuary, North Carolina. Mar. Ecol. Prog. Ser. 71: 259-274

Cole, B. E., Cloern, J. E. (1984). Significance of biomass and light availability to phytoplankton productivity in San Francisco Bay. Mar. Ecol. Prog. Ser. 17: 15-24

Cole, B. E., Cloern, J E. (1987). An empirical model for estimating phytoplankton productivity in estuaries. Mar. Ecol. Prog Ser. 36: 299-305
Falkowski, P. G. (1981). Light-shade adaptation and assimilatjon numbers. J. Plankton Res. 3: 203-216

Fee, E. J. (1973). Modeling primary production in water bodies: a numerical approach that allows for vertical inhomogeneities. J. Fish. Res. Bd Can. 30: 1469-1473

Fisher, T R., Carlson, P. R., Barber, R. T. (1982). Carbon and nitrogen primary productivity in three North Carolina estuaries. Estuar. coast. Shelf Sci. 15: 621-644

Flemer, D. A. (1970). Primary production in the Chesapeake Bay. Chesapeake Sci. 11. 117-129

Harding, L. W., Meeson, B. W., Fisher, T. R. (1986). Phytoplankton production in two east coast estuaries: photosynthesis-light functions and patterns of carbon assimilation in Chesapeake and Delaware Bays. Estuar. coast. Shelf Sci. 23: 773-806

Jassby, A. D., Platt, I. (1976). Mathematical formulation of the relationship between photosynthesis and light for phytoplankton. Limnol. Oceanogr. 21: 540-547

Joint, I. R., Pomeroy, A. J. (1981). Primary production in a turbid estuary. Estuar. coast. Shelf Sci. 13: 303-316

Keller, A. A. (1988). Estimating phytoplankton productivity from light availability and biomass in the MERL mesocosms and Narragansett Bay. Mar. Ecol. Prog. Ser. 45: $159-168$

Kuenzler, E. J., Stanley, D. W., Koenings, J. P. (1979). Nutrient kinetics of phytoplankton in the Pamlico River, North Carolina. Report No. 130, Univ. North Carolina, Water Resour. Res. Inst., Raleigh

Mallin, M. A., Paerl, H. W. (1992). Effects of variable irradiance on phytoplankton productivity in shallow estuaries. Limnol. Oceanogr. 37: 54-62

Mallin, M. A., Paerl, H. W., Rudek, J. (1991). Seasonal phytoplankton composition, productivity and biomass in the Neuse River estuary, North Carolina. Estuar. coast. Shelf. Sci. 32; 609-623

Malone, T C. (1976). Phytoplankton productivity in the apex of the New York Bight: environmental regulation of productivity/chlorophyll a. In: Gross, M. (ed.) The middle Atlantic shelf and New York Bight. Limnol. Oceanogr Spec. Symp., Vol. 2, p. 260-272

McGill, R., Tukey, J. W., Larsen, W. A. (1978). Variations of box plots. American Statistician 32: 12-16

Nixon, S. W. Pilson, M.Q. (1983). Nitrogen in estuarine and coastal marine ecosystems. In: Carpenter, E. J., Capone, D. G. (eds.) Nitrogen in the marine environment. Academic Press, New York, p. 565-648

NCDNRCD (North Carolina Department of Natural Resources and Community Development) (1983). Nutrient management strategy for the Neuse River Basin. Division of Environmental Management. Report No. 83-05, Raleigh

Pennock, J. R. (1983). Regulation of phytoplankton carbon and nitrogen production in the Delaware estuary. Ph.D. thesis, University of Delaware, Lewes

Pennock, J. R., Sharp, J. H. (1986). Phytoplankton production in the Delaware Estuary: temporal and spatial variability. Mar. Ecol Prog. Ser. 34: 143-155

Platt, T (1986). Primary production of the ocean water column as a function of surface light intensity: algorithms for remote sensing. Deep Sea Res. 31: 1-11

Platt, T., Irwin, B. (1971). Phytoplankton production and nutrients in Bedford Basin, 1969-1970. Fish. Res. Bd Can. Tech. Rep. 247

Platt, T., Sathyendranath, S., Caverhill, C. M., Lewis, M. R. (1988). Ocean primary production and available light: turther algorithms for remote sensing. Deep Sea Res. 35: $855-879$ 
Randall, J. M., Day, J. W. (1987). Effects of river discharge and vertical circulation on aquatic primary production in a turbid Louisiana (USA) estuary. Neth. J. Sea Res. 21. $231-242$

Riley, G. A. (1967). The plankton of estuaries. In: Lauf, G. A. (ed.) Estuaries. Publ. Am. Ass. Advmt. Sci., Washington. DC, p. 316-328

Rizzo, W. M., Lackey, G. L., Christian, R. R. (1992). Significance of euphotic, subtıdal sediments to oxygen and nutrient cycling in a temperate estuary. Mar Ecol. Prog. Ser. 86: $51-61$

Stanley, D. W. (1988). Historical trends in nutrient loading to the Neuse River estuary, NC. In: Lyke, W. L., Hoban, T L. (eds.) Proc. Am. Water Resources Ass., Symp. Coastal

This article was presented by T. Platt, Dartmouth, N.S., Canada
Water Issues. AWRA Tech. Publ. Ser. TPS-88-1 AWRA, Bethesda, MD, p. 155-164

Steemann-Nielsen, E. (1952). The use of radioactive carbon $\left({ }^{14} \mathrm{C}\right)$ for measuring organic production in the sea. J. Cons. int. Explor. Mer 18: 117-140

Strickland, J. D. H., Parsons, T R. (1972). A practical handbook of seawater analysis. Bull. Fish. Res. Bd Can. 167 : $1-311$

U.S. EPA (U.S. Environmental Protection Agency) (1979). Methods for chemical analysis of water and wastes. Washington, DC

Wofsy, S. C. (1983). A simple model to predict extinction coefficients and phytoplankton biomass in eutrophic waters. Limnol. Oceanogr. 28: 1144-1155

Manuscript first received: October 30, 1992

Revised version accepted: March 26, 1993 